\title{
A Revisit to China's Foreign Investment Law: With Special Reference to Foreign Investment Protection
}

\section{Yongmin Bian*}

\begin{abstract}
Three foreign investment laws of China were enacted when she was mainly a capitalimporting state. The main purpose of these laws was to boost the Chinese economy with the capital, technology and management of foreign investors. Many preferential treatments, rather than national treatment, were given to foreign investment especially before the country joined the WTO. Following the reform of market economy, fair and equal treatment to foreign investors are replacing the preferential treatments. A new draft of Foreign Investment Law was released in the spring of 2015 to reform the governance of foreign investment by granting national treatment to foreign investors in both admission and operation. The restrictions to foreign investment will be subject to the categories of special administrative measures, which are composed of forbidden and restrictive categories. This is going to be China's biggest reform on the legal system of foreign investment since 1980 s.
\end{abstract}

\section{Keywords}

China's Foreign Investment Law, Equity Joint-Ventures, Contractual JointVentures, Wholly Foreign-Owned Enterprises

\footnotetext{
* Professor of International Law at the University of International Business and Economics Law School. A.B./LL.M. (CUPL), Ph.D. (UIBE). ORCID: http://orcid.org/0000-0002-7950-1160. This research is supported by the Collaborative Innovation Center for China's Multinational Enterprise (No. 201501YY001A). The author may be contacted at: bianyongmin@uibe.edu.cn / Address: 10 Huixin East Street, Chaoyang District, Beijing, 100029, P.R. China. DOI: http://dx.doi.org/10.14330/jeail.2015.8.2.08
} 


\section{Introduction}

Both trade and investment policies have been playing significant roles in China's breathtaking economic development. Chinese trade law has become stable, especially after China became a member of the World Trade Organization ("WTO"), while investment law is still evolving with continuous domestic economic reforms, as well as negotiations for free trade agreements and bilateral investment treaties. Because the current foreign investment laws were adopted about 30 years ago and a fundamental reform is in the undertaking, it is time to review the current foreign investment laws and understand the proposed reforms as well as their probable implications.

The primary purpose of this research is to review and preview China's foreign investment law with special focus on the protection of foreign investment. In doing so, this paper is composed of six parts including a short Introduction and Conclusion. Part two will review the evolution of foreign investment laws of China, showing how the Chinese market opens gradually to foreign direct investment ("FDI"). Part three will analyze the treatments to foreign investment, from the current post-establishment national treatment to the proposed pre-establishment national treatment. Part four will discuss the administrative measures and policies that may affect foreign investment although they are not provided in the three foreign investment laws of China. Finally, Part five will investigate the settlement of disputes arising from foreign investment in China, presenting China's increasing openesss to settle disputes by international tribunals. One feature of Chinese investment laws is how to accommodate Chinese characteristics in the adoption of international practice.

\section{The Evolution of Foreign Investment Laws of China (1970s-80s)}

\section{A. The Beginning}

When China enacted her first foreign investment law in the end of 1970s, nobody could anticipate that China would have started to export its capital 30 years later. As a capital importing State in late 1970s and early 1980s, China decided that her foreign investment law should be different from those of western States, the capital 